\title{
Nasopharyngeal carcinoma among the Bidayuh of Sarawak, Malaysia: History and risk factors (Review)
}

\author{
REAGAN ENTIGU LINTON ${ }^{1 *}$, MAELINDA DAKER ${ }^{1,2^{*}}$, ALAN SOO-BENG KHOO ${ }^{1,2}$, \\ DIANA CHUNG YIING CHOO ${ }^{1}$, MIGNON VILJOEN ${ }^{3}$ and PAUL M. NEILSEN ${ }^{1,3}$ \\ ${ }^{1}$ School of Chemical Engineering and Science, Faculty of Engineering, Computing and Science, \\ Swinburne University of Technology Sarawak Campus, Kuching, Sarawak $93350 ;{ }^{2}$ Molecular Pathology Unit, \\ Cancer Research Centre, Institute for Medical Research, National Institutes of Health, Ministry of Health, \\ Shah Alam, Selangor 40170, Malaysia; ${ }^{3}$ College of Clinical Sciences, School of Health, Medical and Applied Science, \\ Central Queensland University, North Rockhampton, Queensland 4702, Australia
}

Received September 12, 2020; Accepted May 5, 2021

DOI: $10.3892 / \mathrm{ol} .2021 .12775$

\begin{abstract}
Nasopharyngeal carcinoma (NPC) is a cancer of the epithelial cells lining the nasopharynx. The incidence of NPC has a distinct geographical distribution, mainly affecting the Chinese population of Southern China. In Malaysia, this cancer is exceptionally prevalent among males. There is a high incidence rate of NPC among the Bidayuh natives in Sarawak, Malaysia. Other than epidemiology reports, there has not been an article describing plausible cancer risk factors contributing to NPC within this native group. Researchers are still trying to understand the reasons the Bidayuh and Southern Chinese are highly susceptible to NPC. This article discusses the risk factors of developing NPC: Epstein-Barr virus infection, genetic predisposition, diet, environmental exposure and tobacco smoking. There is a need to improve the understanding of the role of risk factors to identify new ways to prevent cancer, especially among high-risk groups.
\end{abstract}

\section{Contents}

1. Introduction

2. Epstein-Barr virus infection

3. Genetic predisposition

4. Diet

Correspondence to: Dr Paul M. Neilsen, College of Clinical Sciences, School of Health, Medical and Applied Science, Central Queensland University, 6 Yaamba Road, North Rockhampton, Queensland 4702, Australia

E-mail: p.neilsen@cqu.edu.au

*Contributed equally

Key words: nasopharynx, nasopharyngeal carcinoma, risk factor, Sarawak, Austronesian, Bidayuh, Iban
5. Environmental exposure

6. Tobacco smoking

7. Other challenges

8. Conclusion

\section{Introduction}

Since 1966, cancer of the nasopharynx has been featured among the top 5 cancers in Malaysia. Between 1981 and 1982, cancer of the nasopharynx was the second most common cancer among males in Sarawak (1). Specifically, from January 1981 to December 1982, the Land Dayak (the name then for Bidayuh, a native ethnic group of Sarawak), had a crude rate of cancer of the nasopharynx of 9.0 per 100,000 population per year, followed by Sarawak Chinese with 5.8 per 100,000 (1).

While Bidayuh was formerly known as Land Dayak, Iban was once referred to as Sea Dayak (2). With regards to history, Dayak comprises the inland or interior groups of people in Borneo (2) and Bidayuh means 'people of the land' (3). Today, Dayak refers to the Iban, Bidayuh and Orang Ulu; Iban forms the largest indigenous category (4). The Bidayuh community is categorised into 4 main groups: i) Biatah; ii) Bau-Jagoi; iii) Bukar-Sadung; and iv) Salako-Rara (5). The estimated Bidayuh population size in 2020 was 220,000 (6).

The island of Borneo comprises the East Malaysian states of Sabah and Sarawak, the Malaysian federal territory of Labuan, the country Brunei and the Indonesian territory known as Kalimantan. The initial settlement of the Bidayuh in Sarawak, $\sim 1,000$ years ago, was Bung Bratak, among others. The ancestors of Bung Bratak inhabitants were originally from Gunong Sunkong, Kalimantan (2). The Bidayuh migrated from the western part of Borneo island (3) or West Kalimantan, while the Iban generally migrated from Kalimantan (7).

Between the years 2012-2016, cancer of the nasopharynx was the fifth most common cancer among Malaysian residents. Also, cancer of the nasopharynx was the fifth most common cancer in Malaysian male residents. It was the fourth 
most common cancer in Malaysian Chinese males. Notably, nasopharynx cancer is the top common cancer among males in Sarawak (8). The uniqueness of this situation in Sarawak contrasts with the pattern of cancer incidence in other states in Malaysia, where colorectal cancer and lung cancer exceed nasopharyngeal cancer (8). Additionally, in 2007-2011, the nasopharynx was the most common cancer site among Sarawak males of Bidayuh or Iban ethnicity (9). Nevertheless, other ethnic groups of Sarawak, such as Chinese, Malay, and Melanau were also at increased risk (9). From 2007-2011, the age-standardised rate (ASR) in Sarawak was 11.6 per 100,000 population and 4.8 per 100,000 in males and females, respectively; with a male to female ASR ratio of 2.4:1 (9). Specifically, the ASR for Bidayuh males and females, respectively, was 24.6 and 9.3 per 100,000 (9). The Iban people had an ASR of 12.0 per 100,000 for males and 4.7 per 100,000 females (9). Among the Chinese, the ASR was 11.2 per 100,000 for males and 4.1 per 100,000 for females (9). The ASR for Malay males was 8.1 per 100,000, while for Malay females, the ASR was 4.5 per 100,000 (9). Finally, amongst Melanau, the ASR was 4.7 per 100,000 and 1.9 per 100,000 in males and females, respectively (9). Notwithstanding ethnicity, the incidence ratio was 2-3 folds higher in males compared with females. Worldwide, between 2008-2012, Zhongshan City, China, had the highest ASR for males $(25$ per 100,000) while Zhuhai, China, had the highest ASR for females (9 per 100,000) (10). The ASR among Bidayuh people was very similar to the highest ASR internationally. Meanwhile, GLOBOCAN 2020 estimates the world ASR at 2.2 per 100,000 for males and 0.8 per 100,000 for females (11). The reasons males are more frequently affected compared with females may be due to genetic susceptibility affected by the X-chromosome (12), or oestrogen sex hormone-associated (13), lifestyle, behaviour, environment or a combination of these factors (14).

Several types of tumours may develop at the nasopharynx, the most common being nasopharyngeal carcinoma (NPC) $(15,16)$. The Fossa of Rosenmüller is usually the site of origin (17). NPC has been associated with various risk factors (Fig. 1) $(18,19)$, suggesting multifactorial causation. The present review discusses several of these risk factors focusing on the Malaysian scenario, particularly among the Bidayuh of Sarawak.

\section{Epstein-Barr virus infection}

The risk for certain types of cancers increases with persistent infection of bacteria, parasites, or viruses (20). Among the cancer-causing viruses are Epstein-Barr Virus (EBV), which may cause Hodgkin and certain non-Hodgkin lymphomas, stomach cancer and NPC (20). EBV belongs to the herpesvirus family, and it is ubiquitous (21). It is present in $>90 \%$ of the world's population (21). In places where NPC is endemic, $>95 \%$ of cases are associated with EBV (22). EBV infection in NPC is predominantly latent $(23,24)$. Recently, specific EBV variants such as non-synonymous EBV variants within BALF2 (SNP 162476_C and SNP 163364_T), were suggested to be associated with NPC (25-29). Inspite of multiple in vitro and in vivo experiments, studies have demonstrated that EBV infection by itself is insufficient for the tumorigenic transformation of epithelial cells $(23,30)$. The role of EBV in the pathogenesis of NPC has been investigated widely and comprehensive reports are available $(23,31-37)$. The present review will not cover the topic of EBV-encoded latent genes such as, EBV-encoded small RNAs, EBV nuclear antigen 1, latent membrane protein 1, latent membrane protein 2 and Bam H1 A rightward open reading frame 1 and lytic genes, such as the immediate early transactivator BZLF1.

\section{Genetic predisposition}

Inheritance of cancer-predisposing genetic mutations is linked to certain cancers, including leukaemias and lymphomas, breast, ovarian, pancreatic, prostate, skin cancer and NPC (20). A family history of any cancer, especially NPC, contributes independently or mutually to NPC risk factors $(38,39)$. Individuals with a first-degree relative with NPC have an elevated risk of developing NPC (38). In endemic regions, this familial risk is substantial due to shared genetic susceptibility among relatives or environmental risk factors (38). In the endemic area of Guangdong, China, the combination of family history of cancer or history of NPC and consumption of salt-preserved fish was significantly associated with risk of NPC; higher than the individual risk of family history alone or consumption of salt-preserved fish alone (38). A recent report suggests that familial risk of NPC may be associated with host response to EBV (40).

A genetic hereditary study of the Chinese population of Southern China and the Bidayuh population found that the Bidayuh genetic material shared similarity with ancestor lineage that could have originated from South China or Indochina 10,000-30,000 years ago, preceding the Austronesian expansion (41). From a linguistic perspective, the language of the Bidayuh belongs to the Austronesian family (42). Based on genetic and anthropological epidemiology, cultural and linguistic similarity, it was hypothetically proposed that a common ancestral origin exists between the Bidayuh and the Bai-Yue tribe (proto-Austronesian people), the reference population postulated for NPC origin of Southern China (43). In addition, it was found that mitochondrial DNA (mtDNA) of the Bidayuh was $60 \%$ similar to the Bai-Yue $(41,44)$. As ancestral populations migrated out from Taiwan, one of the proposed dispersal centres of Austronesian speakers (45), the inheritance of NPC susceptibility gene(s) from Austronesian ancestors may explain why the Bidayuh and Bai-Yue have a genetic predisposition to NPC (16). A 1998-2003 study involving patients with NPC in Guangzhou, China, detected a novel 4981 bp deletion in mtDNA in $93 \%$ of cases, in contrast to the most abundant 4977 bp common deletion (CD) (46). The aforementioned report indicated that CD-mtDNA mutation may be implicated in NPC development and progression (46). In 1997-1998, a study in patients with NPC in Guangzhou, China, demonstrated somatic mutations and polymorphisms in mtDNA, such as $\mathrm{A} \rightarrow \mathrm{G}$ substitution at np15769 and $\mathrm{C} \rightarrow$ T substitution at np15970 (47). Polymorphisms found included np $292 \mathrm{~T} \rightarrow \mathrm{C}$, np16242C $\rightarrow \mathrm{A}, \mathrm{np} 16038 \mathrm{~A} \rightarrow \mathrm{G}$ and $n p 15787 \mathrm{~T} \rightarrow \mathrm{C}(47)$. Sequence variants in $\mathrm{mtDNA}$ had been reported to be associated with genetic susceptibility to familial NPC in the Zhejiang area, China (48). A 2001-2004 study of patients with NPC within the Chaoshan population of China on mtDNA sequence variation identified variants significantly 


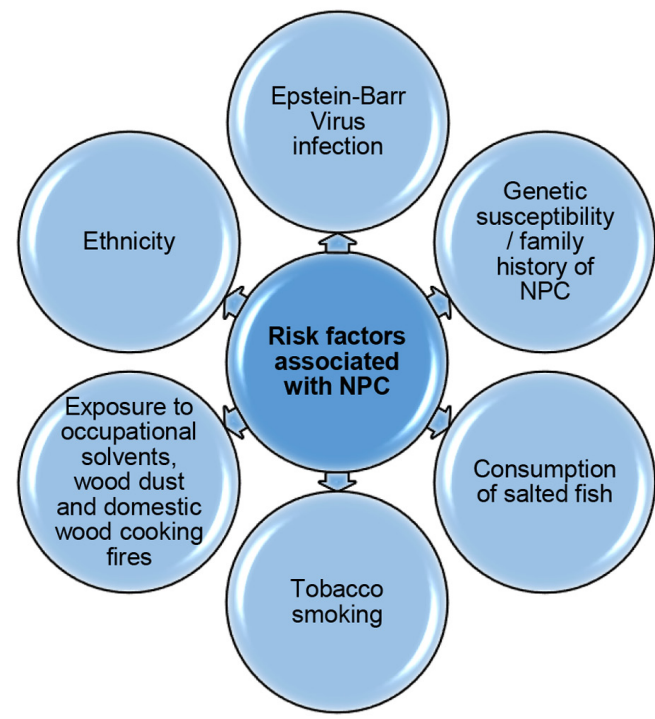

Figure 1. Multiple factors that contribute to the development of NPC include viral and non-viral hazards. NPC, nasopharyngeal carcinoma.

associated with NPC risk (49). In addition, mtDNA haplogroup distribution has demonstrated that the haplogroup R9 and its sub-haplogroup F1 are positively associated with NPC risk (49). However, the manner in which susceptibility genes cause NPC remains unknown, and the biological impacts of mtDNA mutations are still unclear $(46,47)$. In addition, to the best of our knowledge to date there has been no study on the mtDNA of the Bidayuh that may contribute to NPC.

Studies of HLA allele frequencies are essential for anthropology and understanding human migration patterns (50). In 2009, a study encompassing the Bidayuh pinpointed the frequent detection of alleles $A^{*} 3401$ and $B * 1521$ (51). These alleles were also common in Australian aborigines, but rare in most other Southeast Asians (51). Furthermore, the Bidayuh also have high frequencies of DRB1*1602, similar to the Papua New Guinea Lowlanders who linguistically also have Austronesian origins (51). Comparisons of HLA allele frequencies showing genetic similarities further strengthen the school of thought that the Bidayuh and ancient Bai-Yue Chinese tribe share common ancestry of Austronesians but were geographically separated via migration waves.

HLA alleles are not known oncogenes (52). Hence, HLA by itself, is not responsible for NPC development (53). Instead, suppression of immune response presented by HLA alleles may enable immune evasion of EBV-infected NPC cells (23), hence permitting NPC cell survival. According to an HLA polymorphism study, the genetic distance between Bidayuh and Iban was relatively short, with a value of 0.00986 , explaining the Iban's genetic predisposition to NPC being similar to the Bidayuh (50). Studies of the genetic linkage of the Bidayuh and Iban especially in regard to immune responses warrants further attention.

\section{Diet}

Sarawak's people take pride in their ethnic native food, which has become the state's identity (54). Sarawak's geographical terrain, particularly during pre-independence and the lifestyle then, resulted in the forests becoming the source of traditional foods (54). Given that the exclusive preparation methods of ethnic cuisine are passed down from one generation to another, traditional food is continually consumed (54).

A high salt diet posed an increased risk of developing various types of cancers, such as gastric cancer $(55,56)$, whereas salted fish consumption showed a discernible positive association with NPC (57). Notably, the ethnic group with the highest incidence rates for both nasopharyngeal carcinoma and gastric cancers amongst the men in Sarawak was reported to be the Bidayuh, followed by the Chinese and Ibans (9). The Bidayuh population consumes preserved pork and fish (58) that could have increased their risk of developing NPC, a hypothetical observation given the diet of the Chinese, another high-risk NPC population, which consists of a high amount of salted food (59). In accordance, in Guangdong province, Southern China, a significant relationship exists between monthly regular salted fish consumption and increased NPC risk (60), especially during childhood (61). Salted vegetables and preserved meat are other risk factors for NPC (61). Among Malaysian Chinese in the state of Selangor, a history of any kind of salted fish intake in childhood which may continue into adolescence was a significant risk factor for NPC $(62,63)$.

Salt is used to preserve food, such as raw or cooked meat and vegetables to inhibit microorganism growth during extended storage (64). Unless the food undergoes a quality check to monitor the amount and usage of preservative compounds, which is possible if produced in factories, there is no limit set for homemade preserved food (64). Salted fish contains $\mathrm{N}$-nitrosamines. On top of that, salt used in preserving food is crude sea salt (62). Unlike pure sodium chloride, sea salt contains nitrates and nitrites which could produce nitrosamine, a carcinogenic compound (65) formed from various stomach reactions between nitrates and nitrites with secondary amines $(62,66)$. Nitrosamines induce methylation of DNA that may activate proto-oncogenes, such as ras or myc or inactivate suppressor genes such as, p53 or cyclin-dependent kinase inhibitor 2A $(67,68)$. In addition, N-nitroso compounds and high salt consumption was found to reactivate EBV from the latent stage $(69,70)$, which could further increase the risk of NPC (71).

\section{Environmental exposure}

Exposure to hazardous environmental pollutants, occupational agents and inhaled carcinogens could increase an individual's risk of developing NPC $(63,72)$. This relationship could be attributed to the nasopharynx's ability to trap dust and smoke particles from inhaled air, which eventually leads to inflammation $(63,72)$. Given that dust and smoke are of the correct particulate matter size and weights able to be deposited in the nasopharynx, inhaled dust and smoke present as reasonable biological risk factors for NPC $(63,72)$.

In Sarawak, the timber industry is an important economic industry which contributes to numerous wood-based products for export (73). Sawmills that process timber for wood planks use various hazardous chemicals, such as phenol-formaldehyde resin and urea $(74,75)$. The usage of phenol-formaldehyde increases the chance of getting NPC 1.83-fold (76). A study conducted in the United States found that occupational 
exposure to formaldehyde increases NPC risk (77). The Guangdong province of Southern China, with high NPC incidence, is also well-known for wood-based industries (78). Wood-based productions emit significant amounts of formaldehyde and other total volatile organic compounds, such as terpene (78). Wood dust was associated with a considerable risk of developing upper respiratory cancers in a study conducted in New York, United States (79). In a 1990-1992 study of NPC (all squamous cell carcinoma) among the Malaysian Chinese of Selangor and Federal Territory of Kuala Lumpur, wood dust was associated with NPC (72). The significant association between all kinds of dust and exposure to wood smoke with NPC was also reported earlier among the Chinese of Selangor (63). In Nigeria, exposure to cooking wood fumes was the commonest and a significant risk factor associated with malignancies in the nasopharynx among females (80). Some communities in Sarawak still prefer food cooked using firewood (81). The smoke produced by burning charcoal contains various hazardous chemicals that are carcinogenic, such as dimethylbenzathracene and benzanthracene (82). Incomplete burning of wood fires used in cooking produces smoke particles that could be deposited in the nasopharynx $(63,72)$.

Rubber processing factories use chemicals during vulcanisation to change raw rubber properties to more durable products, such as tyres, window seals, tubes and shoe soles yielding nitrosamines, such as $\mathrm{N}$-nitrosodimethylamine, $\mathrm{N}$-nitrosodiethylamine, $\mathrm{N}$-nitrosodibutylamine, $\mathrm{N}$-nitrosopiperidine, $\mathrm{N}$-nitrosopyrrolidine and $\mathrm{N}$-nitrosomorpholine $(83,84)$. Exposure to a high concentration of nitrosamines in German rubber factory workers increased their risk of developing respiratory cancers (85). Rubber is a main contributor from the agricultural sector to Malaysia's economy (86). Sarawak's administration and farmers favour the rubber industry compared to rice because of its price and market demand $(87,88)$. Malaysian rubber tappers are exposed to formic acid, wood smoke and talc powder while producing rubber sheets (63). Rubber processing was significantly related to NPC development in Selangor Chinese (63). Formaldehyde is another principal chemical used in the production of natural rubber (78). It is currently speculated that formaldehyde is a significant risk factor for NPC, especially among rubber industrial workers exposed to various chemicals without proper precautions or personal protection equipment (78). Rubber industrial workers have a higher chance of developing NPC compared with individuals not exposed to formaldehyde (78).

As of 2010, almost half of the Bidayuh population are working in the service sector (6). However, back in 1947, close to $99 \%$ of Bidayuh participated in agriculture (6). Given the high dependency of Sarawak's people on agricultural produce, open burning is still practised during land clearing before planting, primarily in rural areas $(89,90)$. The smoke produced may adversely affect the inhabitants' health. Burning incense and mosquito coils were also found to increase the risk of NPC by 5.9-folds in users compared with non-users (75).

To the best of our knowledge, no studies have been performed to date associating environmental exposure to occupational solvents, wood dust, and domestic wood cooking fires to the high incidences of NPC among the general Sarawak population and the Bidayuh in particular. Hence, future epidemiological studies addressing these risk factors within the Bidayuh of Sarawak need to be conducted.

\section{Tobacco smoking}

The risk of developing cancer increases with smoking tobacco, which exposes an individual to toxins that may cause genetic mutations, such as nicotine and tar (20). Smoking tobacco causes cancers of the lung, nasal cavity, nasopharynx, oral cavity, digestive system and urogenital system (20). There is no level of exposure to tobacco smoke, including exposure to second-hand smoke, which is considered safe (20). Notwithstanding the specific indigenous category, natives of Sarawak had a $37.9 \%$ prevalence of second-hand smoke exposure at home (91). In comparison, exposure at work was $25.7 \%$ (91). Tobacco smoking is one of the critical risk factors for NPC, supported by multiple studies, including those conducted in Malaysia (72) and Thailand (92).

Cigarette smoking is another factor that contributes to NPC (18). Cigarettes contain compounds that are carcinogenic for humans, including nitrosamine, polycyclic aromatic hydrocarbons and free radicals $(68,93)$. Cigarette smoke may damage DNA in mucosal cells that line the airway (93), which may initiate cancer formation. A meta-analysis revealed a modest, but significant association between current cigarette smokers and NPC vs. those who have never smoked (94). Smokers, especially among older people $(95,96)$ and early age of exposure to smoking $(94,97)$, have a higher risk of developing NPC compared with non-smokers. The risk of developing NPC increases with the intensity of cigarettes smoked per day and smoking duration $(92,94,98)$. Among Sarawak natives, the prevalence of any tobacco product use was $26.9 \%$; $24.5 \%$ for tobacco smoking and $23.2 \%$ for cigarette smoking (91). Irrespective of sex, the prevalence of current cigarette smokers in Malaysia aged 15-19 years is $11.6 \%$ (91). A study conducted in Sarawak showed that the habit of smoking could start as early as 12 years old, with $\sim 30 \%$ prevalence among students (99).

None of the aforementioned studies investigated the association between tobacco smoking and NPC development in the Sarawak population in general or the Bidayuh in particular. Nevertheless, it is plausible that such prevalence of smoking may largely contribute to the high risk of developing NPC, especially when smoking begins at a young age.

\section{Other challenges}

In 1947, $29 \%$ of the Bidayuh were rural dwellers (6). As of $2010, \sim 70 \%$ of Bidayuh lived in rural areas (6). Patients with NPC may live in rural areas, where geographical terrain and accessibility pose a challenge (100). Hospitals may be very far and there may be no efficient transport facilities other than logging roads or rivers (100). Such challenges could deter patients from seeking treatment (100). Hence, NPC may impact populations with less access to healthcare.

Lack of awareness about NPC among the public was identified as a challenge for the early detection of NPC (101). A Malaysian study to determine the proportions of health literacy 
levels found that $41.5 \%$ of rural respondents had limited health literacy (91). Meanwhile, between ethnicity, the prevalence of possessing limited health literacy was $41.9 \%$ for natives of Sarawak (91). Limited health literacy in the Disease Prevention domain had a $37.6 \%$ prevalence among Sarawak respondents who were natives (91). The Disease Prevention domain refers to the capability to access, evaluate, interpret and understand information about risk factors and to make informed decisions on the basis of this information (91).

Cancer patients tend to seek some form of complementary and alternative medicine. Complementary medicine was defined by the National Cancer Institute (NCI) as treatments used together with standard medical treatments (20). Alternative medicine, on the other hand, refers to treatments used in place of standard medical treatments (20). However, a number of these complementary and alternative medicines have not been well studied and it remains unknown if these are safe or effective (20). Malaysia is a multicultural and multifaith society that has practised traditional medicine for generations (102). Although by 2010 , slightly $>80 \%$ of the Bidayuh have embraced Christianity, looking back to 1947 , about $91 \%$ of the Bidayuh were firm believers of tribal religion $(2,6)$. Numerous Malaysians believe traditional medicine is more effective and less detrimental to the quality of life compared with modern medicine (102-104). Influence may come from relatives or friends who persuade patients to opt for alternative medicine, believing that it would affect the quality of life less negatively and may be more effective compared with modern medicine (102-104). Patients may resort to alternative medicine halfway through modern medicine without finishing the scheduled prescribed treatment. Incomplete treatment may contribute to ineffective outcomes (102-104). Seeking additional or different treatment from traditional healers may interrupt or delay a patient's scheduled hospital treatment (102-104). Some patients may blindly trust traditional healers, who usually attract interest due to their lower fees compared with doctors (102-104). Regrettably, traditional healers lack knowledge of cancer and cannot treat patients with cancer appropriately (105). Consulting traditional healers has partially contributed to delayed cancer diagnosis and treatment, causing late presentation, advanced stage diagnosis and higher cancer mortality rates (105). Sometimes patients do not disclose their use of alternative medicine (106). Non-disclosure could be due to fear that their scheduled treatment may be put on hold if discovered by doctors (106). Such a habit may be dangerous as alternative medicines may counteract with prescription drugs. Limited health literacy may cause patients to choose alternative medicine while abandoning modern medicine $(105,107)$. Lack of awareness about NPC, topography limitations and usage of different treatments are 3 challenges conceivably present in the Bidayuh community that may deter early detection of NPC and the pursuit of practical and modern treatment.

Limitations of this review are the absence of studies associating dietary habits, tobacco smoking and environmental exposure to NPC development in the Sarawak population in general or the Bidayuh in particular. Investigations addressing these risk factors within this population are warranted. The novelty of this review is that there has not been an article focusing on the trend and high incidence rate of NPC among the Bidayuh of Sarawak, Malaysia. The relevance from an anthropological perspective was also presented in the present review, linking the Bidayuh to the Bai-Yue population of Southern China postulated for NPC origin.

\section{Conclusion}

The aetiology of NPC is probably multifactorial, with all the factors acting together $(18,19)$. Studies investigating the cause of the high incidence of NPC amongst the Bidayuh population would be useful to help us understand this cancer. The possible roles of viral, environmental, dietary factors, host genetics and immune factors make the study of NPC a unique opportunity to investigate multifactorial interaction in cancer's aetiopathogenesis.

\section{Acknowledgements}

We thank Tan Sri Dr Noor Hisham Abdullah, the Director General of Health, Ministry of Health, Malaysia, for his permission to publish this article.

\section{Funding}

No funding was received.

\section{Availability of data and materials}

Data sharing is not applicable to this article, as no datasets were generated or analyzed during the current study.

\section{Authors' contributions}

REL and MD were equal and major contributors in writing the manuscript and confirm the authenticity of all the raw data. ASBK critically revised the manuscript for important intellectual content. DCYC and MV were involved in drafting the manuscript. PMN contributed to the manuscript conception and design and reviewed the final version to be published. All authors have read and approved the final manuscript.

\section{Ethics approval and consent to participate}

Not applicable.

\section{Patient consent for publication}

Not applicable.

\section{Competing interests}

The authors declare that they have no competing interests.

\section{References}

1. Dawie Usop AK: Epidemiology of cancer in Sarawak, East Malaysia. Southeast Asian J Trop Med Public Health 16: 584-590, 1985.

2. Tan CB: Communal associations of the indigenous communities of Sarawak: A study of ethnicity and national integration. Institute of Advanced Studies, University of Malaya, Kuala Lumpur, 1994. 
3. Johari S, Shuib A, Ramachandran S, Herman S and KunasekaranP Bidayuh Community of Malaysia: Presenting culture and nature as a package for sustainable development of indigenous tourism. In: Balancing Development and Sustainability in Tourism Destinations: Proceedings of the Tourism Outlook Conference 2015. Saufi A, Andilolo IR, Othman N and Lew AA (eds). Springer Singapore, Singapore, pp89-96, 2016.

4. Tan CB: Indigenous people, the state and ethnogenesis: A study of the communal associations of the 'Dayak' communities in Sarawak, Malaysia. J Southeast Asian Stud 28: 263-284, 1997.

5. Bongarrá M, Kayad FG and Campbell YM: The Bidayuh-languages or dialects? In: Selected Papers of the Bidayuh Language Development and Preservation Project (2003-2017). Bongarrá M, Arritt M and Kayad FG (eds). Dayak Bidayuh National Association, Kuching, Sarawak, pp207-219, 2017.

6. Kheung LC and Adruce SA: The demographic profile and sustainability growth of the Bidayuh population of Sarawak. Int J Acad Res Bus Soc Sci 8: 69-68, 2018.

7. Chang YM, Swaran Y, Phoon YK, Sothirasan K, Sim HT Lim KB and Kuehn D: Haplotype diversity of 17 Y-chromosomal STRs in three native Sarawak populations (Iban, Bidayuh and Melanau) in East Malaysia. Forensic Sci Int Genet 3: e77-e80, 2009.

8. Azizah AM, Hashimah B, Nirmal K, Siti Zubaidah AR, Puteri NA, Nabihah A, Sukumaran R, Balqis B, Nadia SM, Sharifah SS, et al: Malaysia national cancer registry report 2012-2016. National Cancer Institute Malaysia, pp1-116, 2019.

9. Epidemiology of cancer in Sarawak 2007-2011. Sarawak Cancer Registry, Malaysia, 2017

10. Bray F, Colombet M, Mery L, Piñeros M, Znaor A, Zanetti R and Ferlay J (eds): Cancer Incidence in Five Continents. Vol 11 (electronic version). International Agency for Research on Cancer, Lyon, 2017.

11. Ferlay J, Ervik M, Lam F, Colombet M, Mery L, Piñeros M, Znaor A, Soerjomataram I and Bray F: Global Cancer Observatory: Cancer Today. International Agency for Research on Cancer, Lyon, 2020.

12. Zuo XY, Feng QS, Sun J, Wei PP, Chin YM, Guo YM, Xia YF, Li B, Xia XJ, Jia WH, et al: X-chromosome association study reveals genetic susceptibility loci of nasopharyngeal carcinoma. Biol Sex Differ 10: 13, 2019.

13. Xie SH, Yu IT, Tse LA, Mang OW and Yue L: Sex difference in the incidence of nasopharyngeal carcinoma in Hong Kong 1983-2008: Suggestion of a potential protective role of oestrogen. Eur J Cancer 49: 150-155, 2013.

14. Tang LL, Chen WQ, Xue WQ, He YQ, Zheng RS, Zeng YX and Jia WH: Global trends in incidence and mortality of nasopharyngeal carcinoma. Cancer Lett 374: 22-30, 2016.

15. Chan JJC, Pilch BZ, Kuo TT, Wenig BM and Lee AW: Tumours of the Nasopharynx. In: World Health Organization Classification of Tumours: Pathology and Genetics of Head and Neck Tumours. Barnes L, Eveson JW, Reichart P and Sidransky D (eds). IARC Press, Lyon, 2005.

16. Poh SS, Chua ML and Wee JT: Carcinogenesis of nasopharyngeal carcinoma: An alternate hypothetical mechanism. Chin J Cancer 35: 9, 2016.

17. Khoo AS and Pua KC: Diagnosis and clinical evaluation of nasopharyngeal carcinoma. In: Nasopharyngeal Carcinoma. Busson P (ed). Advances in Experimental Medicine and Biology. Vol 778. Springer, Landes Bioscience, New York, NY, pp1-9, 2013.

18. Chang ET and Adami HO: The enigmatic epidemiology of nasopharyngeal carcinoma. Cancer Epidemiol Biomarkers Prev 15: $1765-1777,2006$

19. Tao Q and Chan AT: Nasopharyngeal carcinoma: Molecular pathogenesis and therapeutic developments. Expert Rev Mol Med 9: 1-24, 2007

20. AACR Cancer Progress Report 2016: Saving Lives Through Research. In: Clinical cancer research. American Association for Cancer Research, ppS1-S137, 2016.

21. Soong YL and Tham IW: Epidemiology of nasopharyngeal carcinoma. In: Nasopharyngeal Carcinoma: Management Strategies. Yom SS and Wee J (eds). Future Medicine Ltd., London, pp5-19, 2014.

22. Stelow EB and Wenig BM: Update from the 4th edition of the world health organization classification of head and neck tumours: Nasopharynx. Head Neck Pathol 11: 16-22, 2017.

23. Tsao SW, Tsang CM, Pang PS, Zhang G, Chen H and Lo KW: The biology of EBV infection in human epithelial cells. Semin Cancer Biol 22: 137-143, 2012.
24. Tsao SW, Tramoutanis G, Dawson CW, Lo AK and Huang DP: The significance of LMP1 expression in nasopharyngeal carcinoma. Semin Cancer Biol 12: 473-487, 2002.

25. Tsai MH, Raykova A, Klinke O, Bernhardt K, Gärtner K, Leung CS, Geletneky K, Sertel S, Münz C, Feederle R and Delecluse HJ: Spontaneous lytic replication and epitheliotropism define an Epstein-Barr virus strain found in carcinomas. Cell Rep 5: 458-470, 2013.

26. Bristol JA, Djavadian R, Albright ER, Coleman CB, Ohashi M, Hayes M, Romero-Masters JC, Barlow EA, Farrell PJ, Rochford R, et al: A cancer-associated Epstein-Barr virus BZLF1 promoter variant enhances lytic infection. PLoS Pathog 14: e1007179, 2018

27. CorreiaS,Bridges R, WegnerF,VenturiniC,Palser A,MiddeldorpJM, Cohen JI, Lorenzetti MA, Bassano I, White RE, et al: Sequence variation of Epstein-Barr virus: Viral types, geography, codon usage, and diseases. J Virol 92: e01132-01118, 2018.

28. Hui KF, Chan TF, Yang W, Shen JJ, Lam KP, Kwok H, Sham PC, Tsao SW, Kwong DL, Lung ML and Chiang AK: High risk Epstein-Barr virus variants characterized by distinct polymorphisms in the EBER locus are strongly associated with nasopharyngeal carcinoma. Int J Cancer 144: 3031-3042, 2019.

29. Xu M, Yao Y, Chen H, Zhang S, Cao SM, Zhang Z, Luo B, Liu Z, Li Z, Xiang T, et al: Genome sequencing analysis identifies Epstein-Barr virus subtypes associated with high risk of nasopharyngeal carcinoma. Nat Genet 51: 1131-1136, 2019.

30. Tsao SW, Wang X, Liu Y, Cheung YC, Feng H, Zheng Z, Wong N, Yuen PW, Lo AK, Wong YC and Huang DP: Establishment of two immortalized nasopharyngeal epithelial cell lines using SV40 large T and HPV16E6/E7 viral oncogenes. Biochim Biophys Acta 1590: 150-158, 2002.

31. Gourzones C, Busson P and Raab-Traub N: Epstein-Barr virus and the pathogenesis of nasopharyngeal carcinomas. In: Nasopharyngeal Carcinoma. Busson P (ed). Advances in Experimental Medicine and Biology. Vol 778. Springer, Landes Bioscience, New York, NY, pp42-60, 2013.

32. Tsang CM, Deng W, Yip YL, Zeng M-S, Lo KW and Tsao SW: Epstein-Barr virus infection and persistence in nasopharyngeal epithelial cells. Chin J Cancer 33: 549-555, 2014.

33. Tsang CM and Tsao SW: The role of Epstein-Barr virus infection in the pathogenesis of nasopharyngeal carcinoma. Virol Sin 30: 107-121, 2015.

34. Tsao SW, Tsang CM and Lo KW: Epstein-Barr virus infection and nasopharyngeal carcinoma. Philos Trans R Soc Lond B Biol Sci 372: 20160270, 2017.

35. Young LS and Dawson CW: Epstein-Barr virus and nasopharyngeal carcinoma. Chin J Cancer 33: 581-590, 2014

36. Tsao SW, Yip YL, Tsang CM, Pang PS, Lau VM, Zhang G and Lo KW: Etiological factors of nasopharyngeal carcinoma. Oral Oncol 50: 330-338, 2014.

37. Tsao SW, Tsang CM, To KF and Lo KW: The role of Epstein-Barr virus in epithelial malignancies. J Pathol 235: 323-333, 2015.

38. Ren ZF, Liu WS, Qin HD, Xu YF, Yu DD, Feng QS, Chen LZ, Shu XO,Zeng YX and Jia WH: Effect of family history of cancers and environmental factors on risk of nasopharyngeal carcinoma in Guangdong, China. Cancer Epidemiol 34: 419-424, 2010.

39. Jia WH and Qin HD: Non-viral environmental risk factors for nasopharyngeal carcinoma: A systematic review. Semin Cancer Biol 22: 117-126, 2012

40. Yu G, Hsu WL, Coghill AE, Yu KJ, Wang CP, Lou PJ, Liu Z, Jones K, Vogt A, Wang M, et al: Whole-exome sequencing of nasopharyngeal carcinoma families reveals novel variants potentially involved in nasopharyngeal carcinoma. Sci Rep 9: 9916, 2019

41. Jinam TA, Hong LC, Phipps ME, Stoneking M, Ameen M, Edo J; HUGO Pan-Asian SNP Consortium and Saitou N: Evolutionary history of continental southeast Asians: ‘early train' hypothesis based on genetic analysis of mitochondrial and autosomal DNA data. Mol Biol Evol 29: 3513-3527, 2012.

42. Noeb J and Ridu RS: Language development in bidayuh: Past, present and future. In: Selected papers of the Bidayuh language development and preservation project (2003-2017). Bongarrá M, Arritt M and Kayad FG (eds). Dayak Bidayuh National Association, Sarawak, pp3-46, 2017.

43. Wee JT, Ha TC, Loong SL and Qian CN: Is nasopharyngeal cancer really a 'Cantonese cancer'? Chin J Cancer 29: 517-526, 2010.

44. Wee J, Ha TC, Loong S and Qian CN: High incidence of nasopharyngeal cancer: Similarity for $60 \%$ of mitochondrial DNA signatures between the Bidayuhs of Borneo and the Bai-yue of southern China. Chin J Cancer 31: 455-456, 2012. 
45. Trejaut J, Lee CL, Yen JC, Loo JH and Lin M: Ancient migration routes of Austronesian-speaking populations in oceanic Southeast Asia and Melanesia might mimic the spread of nasopharyngeal carcinoma. Chin J Cancer 30: 96-105, 2011.

46. Shao JY, Li Y, Gao HY, Mai HQ, Zhang Y, Guo X and Zeng YX High frequency of common deletion (4981 bp) in mitochondrial DNA in nasopharyngeal carcinoma and its correlation with patient age and clinical stages. Cancer Biol Ther 3: 1270-1274, 2004.

47. Pang LJ, Shao JY, Liang XM, Xia YF and Zeng YX: Mitochondrial DNA somatic mutations are frequent in nasopharyngeal carcinoma. Cancer Biol Ther 7: 98-207, 2008.

48. Peng Z, Xie C, Wan Q, Zhang L, Li W and Wu S: Sequence variations of mitochondrial DNA D-loop region are associated with familial nasopharyngeal carcinoma. Mitochondrion 11: 327-333, 2011.

49. Hu SP, Du JP, Li DR and Yao YG: Mitochondrial DNA haplogroup confers genetic susceptibility to nasopharyngeal carcinoma in Chaoshanese from Guangdong, China. PLoS One 9: e87795, 2014.

50. Dhaliwal JS, Shahnaz M, Azrena A, Irda YA, Salawati M, Too CL and Lee YY: HLA polymorphism in three indigenous populations of Sabah and Sarawak. Tissue Antigens 75: 166-169, 2010.

51. Jinam TA, Saitou N, Edo J, Mahmood A and Phipps ME: Molecular analysis of HLA class I and II genes in four indigenous Malaysian populations. Tissue Antigens 75: 151-158, 2010.

52. Goldsmith DB, West TM and Morton R: HLA associations with nasopharyngeal carcinoma in southern Chinese: A meta-analysis. Clin Otolaryngol Allied Sci 27: 61-67, 2002.

53. Lu CC, Chen JC, Jin YT, Yang HB, Chan SH and Tsai ST: Genetic susceptibility to nasopharyngeal carcinoma within the HLA-A locus in Taiwanese. Int J Cancer 103: 745-751, 2003.

54. Ting H, Tan SR and John AN: Consumption intention toward ethnic food: Determinants of Dayak food choice by Malaysians. J Ethn Foods 4: 21-27, 2017.

55. Tsugane S: Salt, salted food intake, and risk of gastric cancer: Epidemiologic evidence. Cancer Sci 96: 1-6, 2005.

56. Song P, Wu L and Guan W: Dietary nitrates, nitrites, and nitrosamines intake and the risk of gastric cancer: A meta-analysis. Nutrients 7: 9872-9895, 2015.

57. Armstrong RW, Imrey PB, Lye MS, Armstrong MJ, Yu MC and Sani S: Nasopharyngeal carcinoma in Malaysian Chinese: Salted fish and other dietary exposures. Int J Cancer 77: 228-235, 1998.

58. Dealwis C: Exogamous marriages between migrant indians with local dayaks and the identity of their offspring. In: International Symposium on Dynamics of Marriage/Divorce Migration Flow in Asia Research Institute for Languages and Cultures of Asia and Africa (ILCAA), Tokyo University of Foreign Studies, pp53-74, 2011.

59. Poirier S, Ohshima H, de-Thé G, Hubert A, Bourgade MC and Bartsch H: Volatile nitrosamine levels in common foods from Tunisia, south China and Greenland, high-risk areas for nasopharyngeal carcinoma (NPC). Int J Cancer 39: 293-296, 1987.

60. Putera I, Ramadhan MG, Anindya S, Sutanto NR, Kurniawan A Hosea FN and Safitri ED: Relationship between salted fish consumption and nasopharyngeal carcinoma: An evidence-based case report. Acta Med Indones 47: 72-77, 2015.

61. Jia WH, Luo XY, Feng BJ, Ruan HL, Bei JX, Liu WS, Qin HD, Feng QS, Chen LZ, Yao SY and Zeng YX: Traditional cantonese diet and nasopharyngeal carcinoma risk: A large-scale case-control study in Guangdong, China. BMC Cancer 10: 446, 2010.

62. Armstrong RW and Eng AC: Salted fish and nasopharyngeal carcinoma in Malaysia. Soc Sci Med 17: 1559-1567, 1983.

63. Armstrong RW, Armstrong MJ, Yu MC and Henderson BE: Salted fish and inhalants as risk factors for nasopharyngeal carcinoma in Malaysian Chinese. Cancer Res 43: 2967-2970, 1983.

64. Babji AS, Aishah S and Aminah A: Nitrite content of some foods in Malaysia. Pertanika 7: 39-41, 1984.

65. Tricker AR and Preussmann R: Carcinogenic N-nitrosamines in the diet: Occurrence, formation, mechanisms and carcinogenic potential. Mutat Res 259: 277-289, 1991.

66. Lin JK: Nitrosamines as potential environmental carcinogens in man. Clin Biochem 23: 67-71, 1990

67. Belinsky SA, Devereux TR and Anderson MW: Role of DNA methylation in the activation of proto-oncogenes and the induction of pulmonary neoplasia by nitrosamines. Mutat Res 233: 105-116, 1990.

68. Nasution II, Lutan R, Munir D and Wahyuni AS: Relationship between cigarette smoking and nasopharyngeal carcinoma. Int J Nasopharyngeal Carcinoma 1: 17-23, 2019.
69. Shao YM, Poirier S, Ohshima H, Malaveille C, Zeng Y de Thé $\mathrm{G}$ and Bartsch H: Epstein-Barr virus activation in Raji cells by extracts of preserved food from high risk areas for nasopharyngeal carcinoma. Carcinogenesis 9: 1455-1457, 1988.

70. Huang SY, Fang CY, Tsai CH, Chang Y, Takada K, Hsu TY and Chen JY: N-methyl-N'-nitro-N-nitrosoguanidine induces and cooperates with 12-O-tetradecanoylphorbol-1,3-acetate/sodium butyrate to enhance Epstein-Barr virus reactivation and genome instability in nasopharyngeal carcinoma cells. Chem Biol Interact 188: 623-634, 2010.

71. Zheng X, Yan L, Nilsson B, Eklund G and Drettner B: Epstein-Barr virus infection, salted fish and nasopharyngeal carcinoma. A case-control study in southern China. Acta Oncol 33: 867-872, 1994

72. Armstrong RW, Imrey PB, Lye MS, Armstrong MJ, Yu MC and Sani S: Nasopharyngeal carcinoma in Malaysian Chinese: Occupational exposures to particles, formaldehyde and heat. Int J Epidemiol 29: 991-998, 2000.

73. Kaur A: A history of forestry in Sarawak. Mod Asian Stud 32: 117-147, 1998.

74. Niemelä R and Vainio H: Formaldehyde exposure in work and the general environment. Occurrence and possibilities for prevention. Scand J Work Environ Health 7: 95-100, 1981

75. West S, Hildesheim A and Dosemeci M: Non-viral risk factors for nasopharyngeal carcinoma in the Philippines: Results from a case-control study. Int J Cancer 55: 722-727, 1993.

76. IARC Working Group on the Evaluation of Carcinogenic Risks to Humans: Formaldehyde, 2-butoxyethanol and 1-tertbutoxypropan-2-ol. International Agency for Research on Cancer, Lyon, 2006.

77. Vaughan TL, Stewart PA, Teschke K, Lynch CF, Swanson GM Lyon JL and Berwick M: Occupational exposure to formaldehyde and wood dust and nasopharyngeal carcinoma. Occup Environ Med 57: 376-384, 2000.

78. Menicagli R, Bolla G, Menicagli L and Esseiridou A: Industrial pollutants and nasopharyngeal cancer: An open question. Gulf J Oncolog 1: 70-74, 2017.

79. Jayaprakash V, Natarajan KK, Moysich KB, Rigual NR, Ramnath N, Natarajan N and Reid ME: Wood dust exposure and the risk of upper aero-digestive and respiratory cancers in males. Occup Environ Med 65: 647-654, 2008.

80. Adoga AA, Kokong DD, Nimkur TL and Ma'an ND: Environmental and life-style related risk factors for sinonasal and nasopharyngeal malignancies among a prospective cohort in Jos, Nigeria. Int J Otolaryngol 2018: 8524861, 2018.

81. Cravioto J, Ohgaki H, Che HS, Tan C, Kobayashi S, Toe H, Long B, Oudaya E, Rahim NB and Farzeneh H: The effects of rural electrification on quality of life: A southeast Asian perspective. Energies 13: 2410, 2020.

82. Kodama AM and Dollar AM: Indoor fires as a possible cause of cancers of the upper respiratory and digestive systems in certain underdeveloped countries. J Environ Health 46: 88-90, 1983.

83. Spiegelhalder B and Preussmann R: Occupational nitrosamine exposure. 1. Rubber and tyre industry. Carcinogenesis 4: $1147-1152,1983$

84. Incavo JA and Schafer MA: Simplified method for the determination of N-nitrosamines in rubber vulcanizates. Anal Chim Acta 557: 256-261, 2006.

85. Straif K, Weiland SK, Bungers M, Holthenrich D, Taeger D, Yi S and Keil U: Exposure to high concentrations of nitrosamines and cancer mortality among a cohort of rubber workers. Occup Environ Med 57: 180-187, 2000.

86. Ratnasingam J, Ramasamy G, Wai LT, Senin AL and Muttiah N: The prospects of rubberwood biomass energy production in Malaysia. BioRes 10: 2526-2548, 2015.

87. Mertz O, Egay K, Bruun TB and Colding TS: The last Swiddens of Sarawak, Malaysia. Hum Ecol 41: 109-118, 2012.

88. Warren-Thomas E, Dolman PM and Edwards DP: Increasing demand for natural rubber necessitates a robust sustainability initiative to mitigate impacts on tropical biodiversity. Conserv Lett 8: 230-241, 2015

89. Hatch T: Shifting cultivation in Sarawak: Past, present and future. In: Tropical Ecology and Development: Proceedings of the Vth International Symposium of Tropical Ecology. Furtado JI (ed). International Society for Tropical Ecology, Kuala Lumpur, pp483-496, 1979.

90. Kendawang JJ, Tanaka S, Shibata K, Yoshida N, Sabang J, Ninomiya I and Sakurai K: Effects of shifting cultivation on soil ecosystems in Sarawak, Malaysia. III. Results of burning practice and Changes in soil organic matter at niah and bakam experimental sites. Soil Sci Plant Nutr 51: 515-523, 2005. 
91. National Health and Morbidity Survey (NHMS) 2019. Technical Report - Volume. 1: NCDs-non-communicable diseases: Risk Factors and Other Health Problems. Institute for Public Health (IPH), National Institutes of Health, Ministry of Health, Malaysia, 2020.

92. Fachiroh J, Sangrajrang S, Johansson M, Renard H, Gaborieau V, Chabrier A, Chindavijak S, Brennan P and McKay JD: Tobacco consumption and genetic susceptibility to nasopharyngea carcinoma (NPC) in Thailand. Cancer Causes Control 23 1995-2002, 2012.

93. Randerath E, Danna TF and Randerath K: DNA damage induced by cigarette smoke condensate in vitro as assayed by 32P-postlabeling. Comparison with cigarette smoke-associated DNA adduct profiles in vivo. Mutat Res 268: 139-153, 1992.

94. Long M, Fu Z, Li P and Nie Z: Cigarette smoking and the risk of nasopharyngeal carcinoma: A meta-analysis of epidemiological studies. BMJ Open 7: e016582, 2017.

95. Chen CJ, Liang KY, Chang YS, Wang YF, Hsieh T, Hsu MM, Chen JY and Liu MY: Multiple risk factors of nasopharyngeal carcinoma: Epstein-Barr virus, malarial infection, cigarette smoking and familial tendency. Anticancer Res 10: 547-553, 1990.

96. Vaughan TL, Shapiro JA, Burt RD, Swanson GM, Berwick M, Lynch CF and Lyon JL: Nasopharyngeal cancer in a low-risk population: Defining risk factors by histological type. Cancer Epidemiol Biomarkers Prev 5: 587-593, 1996.

97. Hsu WL, Chen JY, Chien YC, Liu MY, You SL, Hsu MM, Yang CS and Chen CJ: Independent effect of EBV and cigarette smoking on nasopharyngeal carcinoma: A 20-year follow-up study on 9,622 males without family history in Taiwan. Cancer Epidemiol Biomarkers Prev 18: 1218-1226, 2009.

98. Chow WH, McLaughlin JK, Hrubec Z, Nam JM and Blot WJ: Tobacco use and nasopharyngeal carcinoma in a cohort of US veterans. Int J Cancer 55: 538-540, 1993.
99. Juslina O, Leelavathi M, Khairani O and Iryani T: Prevalence of smoking among secondary school students in Sarawak. Malays Fam Physician 6: 66-67, 2011

100. Devi BCR, Tang TS and Corbex M: Setting up home-based palliative care in countries with limited resources: A model from Sarawak, Malaysia. Ann Oncol 19: 2061-2066, 2008.

101. World Cancer Day 2019: Factsheet for Healthcare Providers. Disease Control Division, Ministry of Health Malaysia, 2019.

102. Ariff KM and Beng KS: Cultural health beliefs in a rural family practice: A Malaysian perspective. Aust J Rural Health 14: 2-8, 2006.

103. Alshagga MA, Al-Dubai SA, Muhamad Faiq SS and Yusuf AA: Use of complementary and alternative medicine among asthmatic patients in primary care clinics in Malaysia. Ann Thorac Med 6: 115-119, 2011

104. Lee PY, Abang Taha AB, Lin K, Ghazali SR and Syed Ahmad Al-Mashoor SH: Usage of complementary and alternative medicine among primary care clinic attendees, Kuching, Sarawak, Malaysia, January-April 2004. Asia Pac Fam Med 6, 2007.

105. Merriam S and Muhamad M: Roles traditional healers play in cancer treatment in Malaysia: Implications for health promotion and education. Asian Pac J Cancer Prev 14: 3593-3601, 2013.

106. Farooqui M, Hassali MA, Abdul Shatar AK, Shafie AA, Seang TB and Farooqui MA: Complementary and alternative medicine (CAM) use by Malaysian oncology patients. Complement Ther Clin Pract 18: 114-120, 2012.

107. Muhamad M, Merriam S and Suhami N: Why breast cancer patients seek traditional healers. Int J Breast Cancer 2012: 689168, 2012.

This work is licensed under a Creative Commons Attribution-NonCommercial-NoDerivatives 4.0 International (CC BY-NC-ND 4.0) License. 